Dr. Abha Chauhan Khimta

\title{
Cleanliness and Sanitation: Gandhian Perspective
}

\author{
Dr. Abha Chauhan Khimta \\ Assistant Professor \\ Department of Political Science \\ Himachal Pradesh University, Shimla, H.P. \\ Email : abhackhimta@gmail.com
}

\begin{abstract}
Gandhi regarded sanitation more important than political independence. He spoke about the need to improve hygiene and cleanliness in the country, while leading a nonviolent movement for India's independence.For Gandhi cleanliness was next to Godliness. In South Africa he tried to destroy the twin evils of untouchability and insanitation. He took to scavenging himself and worked hard to make people aware of cleanliness and sanitation. Similarly after return to India, his interest in the numerous aspects related to the state of insanitation and lack of hygiene then prevalent in India progressively grew in content and scope.Most of the population lived in the villages at that time and he started paying special attention to village sanitation. Gandhi firmly believed that the attainment of swarajwas not possible without attaining cleanliness and sanitation at personal and community levels. Mahatma Gandhi sought to revolutionize not only the aims of development but equally the method of an action which can lead to the achievement of the aims. This paper explores Gandhi's ideas on sanitation and cleanliness and how far they are relevant in the present time.

Keywords: Scavenging, Hygiene, Swaraj,Revolutionise
\end{abstract}

Reference to this paper should be made as follows:

Dr. Abha Chauhan Khimta,

Cleanliness and Sanitation: Gandhian Perspective,

Journal Global Values,

Vol. XI, No.I,

Article No.02,

pp. 12 - 19

https://anubooks.com/ ?page_id $=6838$ 


\section{Introduction}

A nationwide Swacch Bharat Abiyan was launched on $2^{\text {nd }}$ October, 2014 by the prime minister of India to pay tribute to the father of the nation Mahatma Gandhi. In the words of the prime minister clean India was the best tribute India could pay to Mahatma Gandhi on his 150 birth anniversary. The concept of Swachh Bharat is not merely cleaning and sweeping streets. It requires that every family in the country either in villages or towns and cities or in slums in cities must have toilet facility, solid and liquid waste disposal system, village cleanliness and safe and adequate drinking water supply. This was a nationwide movement to evoke a sense of responsibility for cleanliness and sanitation among the masses. At the same time this would be a major step towards prevention of most of the diseased to which man, woman and children fall victim. They are forced to spend large amount of money and their income on curative treatment. This pushes them in to a vicious circle of poverty, malnutrition and mortality.Cleanliness habits must be inculcated among family members and particularly among the children can have great impact in their public behaviour.

The concept of sanitation is very comprehensive in nature. It include effective management of human waste, solid waste, waste water, sewage effluents, industrial wastes and hazardous wastes such as hospital, chemical, radioactive, plastic etc. The standards of sanitation and the levels of hygiene and public health are interrelated with each other in the society. Thelack of sanitation and cleanliness has economic and serious social consequences. Mahatma Gandhi realized early in his life that sanitation and cleanliness in India needed as much attention as was being devoted towards attainment of swaraj. He said, "Unless we rid ourselves of our dirty habits and have improved latrines, swaraj can have no value for us." 1

Gandhi emphasised that cleanliness and sanitation was more important than attaining independence or swaraj.He made theman integral part of Gandhian way of life.Gandhi pointed out the close relationship of cleanliness and good habits with good health.For example, he advised that no one should spit or clean his nose on the streets because the germs in sputum are so harmful that they infect others. While pointing out at the unhygienic habits of the Indians, he wrote on this in Navajivan on $24^{\text {th }}$ May, 1925, "I shall have to defend myself on one point namely sanitary conveniences. I learnt 35 years ago that a lavatory must be as clean as a drawing room. I learnt this in the west. I believe that many rules about cleanliness in lavatories are observed more scrupulously in the west than in the east. There are some defects in their rules in this matter, which can be easily remedied. The cause of many of our diseases is the condition of our lavatories and our bad habit of disposing of excreta anywhere and everywhere. I therefore believe in the absolute necessity of a clean 
Cleanliness and Sanitation: Gandhian Perspective

Dr. Abha Chauhan Khimta

place for answering the call of nature and clean articles for use at the same time. I have accustomed myself to them and wish that all others should do the same. The habit has become so firm in me that even if I wished to change it, I would not be able to do so. Nor do I wish to change it." "Gandhi further wrote on sanitation in Navjivan on $13^{\text {th }}$ September, 1925 under the title of 'our dirty ways' as under: ${ }^{3}$

1. A particular place should be fixed for excretory functions.

2. To pass urine anywhere in a street should be regarded an offence.

3. Urine spot should be covered with dry earth after passing it.

4. Lavatories should be kept very clean. Even the part through which the water flows should be kept clean.

5. All the night soil should be removed to fields.

Gandhi again wrote on the misuse of village tanks in Harijan on $8^{\text {th }}$ February, 1935, "village tanks are promiscuously used for bathing, washing clothes and drinking and cooking purposes. Many village tanks are used by cattle. Buffaloes are often to be seen wallowing in them. The wonder is, in spite of this sinful misuse of village tanks, villages have not been destroyed by epidemics. It is the universal medical evidence that this neglect to ensure the purity of water supply of villages is responsible for many of the diseases suffered by the villagers." ${ }^{4} \mathrm{He}$ further said, "Village sanitation is, perhaps, the most difficult task before the All India Village Industries Association. No Government can change the habits of a people without their hearty cooperation. And if the latter is forthcoming, a Government will have little to do in the matter. The intelligentsia- medical men and students- can deal with the problem successfully if they would conscientiously, intelligently, jealously and regularly do the work in the villages. Attention to personal and corporate hygiene is the beginning of all education. The things to attend to in the villages are cleaning tanks and wells and keeping them clean, getting rid of dung heaps." 5

Mahatma Gandhi also remained deeply involved with sanitation and cleanliness issues in South Africa. White settlers asserted not give equal opportunity to the Indian settlers like traders, labourers and other groups in South Africa because Indians did not follow sanitary and hygienic practices. They asked that Indians should be made to live in separate locations. He said, "Therefore, ever since my settlement in Natal, I had been endeavouring to clear the community of a charge that had been levelled against it, not without a certain amount of truth. The charge had often been made that the Indian was slovenly in his habits and did not keep his house and surroundings clean. The principal men of the community had, therefore, already begun to put their houses in order, but house to house inspection was undertaken 
only when plague was reported to be imminent in Durban. This was done after consulting and gaining the approval of the city fathers who had desired our cooperation. Our cooperation made work easier for them and at the same time lessened our hardships. For whenever there is an outbreak of epidemics, the executive, as a general rule, get impatient, take executive measures and behave to such as may haveincurred their displeasure with a heavy hand. The community saved itself from this oppression by voluntary taking sanitary measures."

Gandhi denounced the divorce between intelligence and labour. By interconnecting internal and external cleanliness, he stated that uncleanliness of mind was more dangerous than that of the body. Gandhi has written in the Satyagraha in South Africa, "Side by side with external agitation, the question of internal improvement was also taken up. The European throughout South Africa had been agitating against Indians on the ground of their ways of life. They always argued that the Indians were very dirty and close-fisted. They lived in the same place where they traded. Their houses were mere shanties. They would not spend money even on their own comforts. How could cleanly open minded European with their multifarious wants compete in trade with such parsimonious and dirty people? Lectures were therefore delivered, debates held, and suggestions make at Congress meeting on subjects such as domestic sanitation, personal hygiene, the necessity of having separate buildings for houses and shops and for well to do traders of living in a style befitting their position. The proceedings were conducted in Gujarati." ${ }^{17}$ Gandhi believed that the unhygienic way of life led to the spread of an epidemic of cholera in the cluster where the Asiatic lived. Gandhi personally led the team of volunteers in cleaning the lavatories and homes of these immigrants. He established a balance between bodily labour and mental work, "only when there is both inner and outer cleanliness, it becomes next to godliness... inward cleanliness is the first thing that should be taught, other things must follow after the first and most important lesson has gone home... our personal cleanliness counts for little if our neighbours are not clean ...Is only that unclean which appears to the eye as unclean? If there is even a little dirt on what is white, we feel annoyed; but the black may have any amount of dirt on it and we care not at all."

Gandhi made sincere attempt to educate masses on the importance of health and hygiene. Through his weekly columns and conservations with the people he worked with them and made them aware of the importance of the cleanliness. Gandhi paid special attention on the village sanitation, as most Indians lived in villages. $\mathrm{He}$

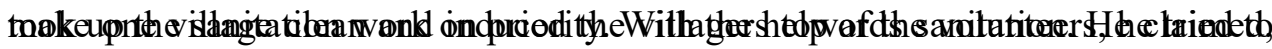
"Divorce between intelligence and labour has resulted in criminal negligence of the 
Cleanliness and Sanitation: Gandhian Perspective

Dr. Abha Chauhan Khimta

villages. And so, instead of having graceful hamlets dotting the land, we have dungheaps. The approach to many villages is not a refreshing experience. Often one would like to shut one's eyes and stuff one's nose; such is the surrounding dirt and offending smell. If the majority of Congressmen were derived from our villages, as they should be, they should be able to make our village models of cleanliness in every sense of the word. But they have never considered it their duty to identify themselves with the villagers in their daily lives. A sense of national or social sanitation is not a virtue among us. We may take a kind of a bath, but we do not mind dirtying the well or the tank or the river by whose side or in which we perform ablutions. I regard this defect as a great vice which is responsible for the disgraceful state of our villages and the sacred banks of the sacred rivers and for the diseases that spring from insanitation." $"$

Gandhi stressed that village workers should become voluntary scavengers. According to him village would lead itself to perfect sanitation. Similarly in 1915, Gandhi wrote about his visit to the KumbhMela in the Hindu holy city of Haridwar. He expressed his grief by writing in Young India in 1919, "I had gone there full of hope and reverence. But while I realized the grandeur of the holy Ganga and the holier Himalayas, I saw little to inspire me in what man was doing in this holy place. To my great grief, I discovered insanitation, both moral and physical...There is defilement of the mighty stream (the river Ganga) even in the name of religion" he further wrote, " Thoughtless ignorant men and women use for natural functions the scared banks of the river where they are supposed to sit in quiet contemplation and find God. They violate religion, science and the laws of sanitation." 10

Gandhian movement for sanitation had taken a much more active form by the time he came out of the jail in 1924. Writing under the title 'Our insanitation', he stressed that a clean body could not reside in an unclean city and insanitation was directly linked to the spread of several diseases.He urged municipalities for having a genuine spirit of service and self sacrifice for keeping the city clean and free from diseases. He firmly believed that one should be rid of insanitation to live in cities. He observed that, "Towns were of considerable importance to the development of a country and we should learn from the west in respect of municipal administration: Glasgow and Birmingham were earlier dirtier than our Gaya but were today places worthy of emulation.Municipalities in holy cities should lead in ensuring sanitation of towns and rivers." 11

Gandhi observed that sanitary workers were treated as untouchablesand this led to the work of sanitation being grossly neglected as unclean. Gandhi considered the bhangi to be probably the most useful member of the society. He believed that 
they should have a thorough knowledge of the principles of sanitation and they should have knowledge of the right kind of latrine and the process of converting night soil and urine into manure.During quit India movement, Gandhi was involved in the political processes and working hard against communal violence. At the same time he also continued to propagate his drive and efforts for sanitation, cleanliness and hygiene. In this period, while most of his references dealt with the subject in broad terms including specific references to the subject of composting the wastes and to sanitation in refugees' camps. He also kept referring to the sad plight of scavengers and to village sanitation. ${ }^{12}$

After India became independent, Gandhi said at Calcutta that he could not be satisfied till it had become known for sanitation. He pointed out that Delhi municipality was not known for cleanliness. He was deeply concerned about the insanitary conditions in the refugee camps after partition of the nation.In his broadcast to refugees at Kurukshetra camps, he said, "You must take the sanitation of the place in your hands." ${ }^{13} \mathrm{He}$ even asked them to help the doctors and officials in keeping the camp clean and advised refugees in India and Pakistan to be their own scavengers.After independence, he strongly asserted the need to recycle all organic waste by composting it into manure.

Similarly several decades ago he had drawn attention to the fast dying holy rivers, "We have more Ganges and Jamunas than the two... They remind us of the sacrifices we must make for the sake of the land we are living in. They remind us of the sacrifice we must make for the sake of the land we are living in. They remind us of the process of purification that we must continuously go through as the rivers themselves are going through from movement to movement...In the modern rush, the chief use we have for our rivers is to empty our gutters in them and to navigate our cargo vessels, and in the process make them dirtier still. We have no time... to stroll down to these rivers, and in silent meditation listen to the message they murmur to us." ${ }^{14} \mathrm{He}$ stated, "All the religion in the world prohibit the pollution of streams, their banks, public roads and all thoroughfares. Science teaches us that human evacuations, whether liquid or solid, make most valuablw manure if they are properly conserved. Hygienists regard it as a crime against humanity for any person to perform natural functions in the places enumerated by me." 15 Eventoday these profound words seem so fresh.

Sanitation is a joint responsibility of the individuals, communities and state. There are multiple institutional systems, including departments and municipal and medical systems meant to look after sanitation in post independence India. Under Swachh Bharat Abhiyan Government of India plans to cover the following major 
Cleanliness and Sanitation: Gandhian Perspective

Dr. Abha Chauhan Khimta

parameters of sanitation:

No open defecation. The target is construct toilets in every home by 2019 .

All waste water to be released into water bodies only after treatment.

Ban on defecation/ urination etc. on the banks of streams.

Subsidy for construction of toilets.

Adequate number of toilets and urinals at all public and institutional units, such as educational institutions, railway stations, bus stops, trains etc.

Thus Gandhian movement were multifaceted but was related to the situation of his time. At that period of time India was mostly a rural and under developed country. Gandhi was remarkably modern and remains equally relevant today. $\mathrm{He}$ interlinked the issues of sanitation, cleanliness and hygiene with the issues of waste generation and its management. He can be regarded as the first leader to repeatedly emphasize that the responsibility for sanitary living applied equally at personal, domestic and corporate level.

\section{References}

1 Collected Works of Mahatma Gandhi, Vol. 14 (New Delhi: Publication Division, Ministry of Information and Broadcasting, 1958-94), pp. 56-58.

2 B.B.Patil, "Gandhiji on Cleanliness, Sanitation, Hygiene and Environment" https:// mgli.gujarat.gov.in/images/mahatma-gandhi/Gandhijiartical.pdf, accessed on 2.4.2020.

3 B.B. Patil, "Gandhi on Cleanliness, Sanitation, Hygiene and Environment," op.cit.

4 B.B.Patil, "Gandhi on Cleanliness, Sanitation, Hygiene and Environment," op.cit.

5 Speeches and Discourses of Mahatma Gandhi on Cleanliness and Sanitation, compiled from The Collected Works of Mahatma Gandhi (New Delhi: Publication Division), p.21. https://www.tcil-india.com/swachh bharat /speech.pdf, accessed on 2.4.2020.

6 Shriman Narayan ed.,The Selected Works of Mahatma Gandhi, Vol. I (Ahmedabad: Navajivan Publishing House, 1968), p.324.

7 Dr.Savita Singh, 'Cleanliness is next to Godliness' M.K.Gandhi, p.2/17, https:// www.mkgandhi.org/articles/cleanliness-next-to-godliness.html, accessed on 2.4.2020

8 Dr.Savita Singh, 'Cleanliness is next to Godliness' M.K.Gandhi, op.cit. p. 3/17.

$9 \quad$ The Selected Works of Mahatma Gandhi, Vol. 4, ed. By Shriman Narayan

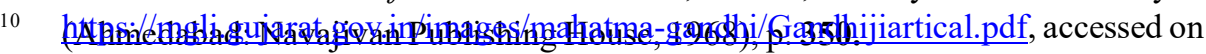


2.4.2020.

11 Dr.Y.P.Anand, “Cleanliness-Sanitation: Gandhian Movement and Swachh Bharat Abhiyan,"p.10/33 https://www.mkgandhi.org/articles/cleanliness-sanitationgandhian-movement-swachh-bharat-abhiyan.html, accessed on 2.4.2020.

12 Dr.Y.P.Anand, “Cleanliness-Sanitation: Gandhian Movement and Swachh Bharat Abhiyan," op.cit.P.15/33.

13 Dr.Savita Singh, 'Cleanliness is next to Godliness' M.K.Gandhi,op.cit. P.14/17.

14 Dr.Y.P.Anand, “Cleanliness-Sanitation: Gandhian Movement and Swachh Bharat Abhiyan,"op.cit. P. 28/33.

15 Speeches and Discourses of Mahatma Gandhi on Cleanliness and Sanitation, compiled from The Collected Works of Mahatma Gandhi,op.cit.p. 17. 